\title{
APSA Releases New Book on Civic Engagement
}

APSA published a new book in February, Teaching Civic Engagement: From Student to Active Citizen, edited by Alison Rios Millett McCartney, Elizabeth A. Bennion, and Dick Simpson. Preface author Rick Battistoni notes the importance of the book as a timely resource to educate for political engagement and as the culmination of over a decade of work by political scientists and APSA. These include numerous conference events, papers, and articles, (many of which appear as chapters in this book), associationsponsored online activities and resources, and a special service learning section in the September 2000 PS. In the foreword, APSA executive director Michael Brintnall echoes Battistoni's assessment of the work as "a rich collection of research and innovative pedagogy that helps reaffirm APSA's voice in civic engagement and advances and reshapes the commitment with which the association began." Brintnall notes that the book emerges in tandem with "the intellectual laboratory" of the annual APSA Teaching and Learning Conference, work of APSA committees on teaching and learning and civic education and engagement, the Alma Ostrom and Leah Hopkins Awan Civic Education Fund of the APSA Centennial Center, and other current related association activities.

Written by political scientists representing a range of research interests, subfields, and institution types, Teaching Civic Engagement makes the case that civic and political engagement should be a central part of the mission of the discipline. In 27 chapters and four major sections, more than 30 authors explore key practices and offer subfield-specific pedagogical examples of educating student citizens in the 21st century and advocate for the centrality of civic engagement education in political science. Section One reviews debates, definitions, benefits, challenges of civic engagement; multiple modes of engagement in higher education; bridging adolescent and adult engagement; civic engagement pedagogy and political science education; and political science faculty as models of engagement. Section Two covers how to implement civic engagement in the political science classroom and speaks to specific subfields and topics including urban, local, and state government; public policy and public law; American government and elections; political philosophy; comparative politics and international relations; internships; and high school civics. Section Three provides guidance on formulating appropriate learning outcomes and objectives and incorporating civic engagement into the curriculum and all aspects of college life such as study-abroad programs, internships, and student organizations. Section Four supplies readers with an assessment toolkit to rigorously evaluate engagement activities and an overview of civic engagement research in political science journals. The book concludes with a call to political scientists to reflect on their teaching and research as it relates to civic learning and engagement and defines an action plan for the discipline toward civic and political engagement. APSA created a website companion to the book, compiled and developed by online supplement editor Elizabeth Matto. The site opens public access to civic engagement materials and teaching resources cited within the book and additional sources (www.apsanet. org/teachingcivicengagement).

APSA encourages all political scientists to add the Teaching Civic Engagement book to their personal libraries. The table of contents and a preview of the first 38 pages are available on the book website. For more information and to place an order, visit website www.apsanet.org/ teachingcivicengagement. Book details: Teaching Civic Engagement: From Student to Active Citizen, (State of the Profession Series); \$46.50. 536pp. February 2013. ISBN 978-1-878147-40-0.

\section{3-2014 APSA Minority Fellows Named}

I $\mathrm{n}$ recognition of their outstanding academic and personal achievements, APSA is pleased to announce the APSA Minority Fellows for the 2013-14 academic year. The Minority Fellows Program (MFP) was established in 1969 as an effort to increase the number of minority scholars in the discipline and has designated more than 400 fellows and contributed to the successful completion of doctoral political science programs for over 100 individuals. APSA has refocused and increased its efforts to assist minority students in completing their doctorates by concentrating not only on the recruitment of minorities, but also on the retention of these groups within the profession. The MFP designates up to 12 stipend minority fellows each year. Fellows with stipends receive a $\$ 4,000$ fellowship that is disbursed in two \$2,0oo payments-one at the end of their first graduate year and one at the end of their second-provided that they remain in good academic standing. Awards are based on students' undergraduate course work, GPA, extracurricular activities, GRE scores, and recommendations from faculty. Members of the selection committee for this year's fellows included Sonia Garcia, Committee on the Status of Latinos y Latinas in the Profession; B. D'Andra Orey, Committee on the Status of Blacks in the Profession; and Wendy K. Tam Cho, Committee on the Status of Asian Pacific Americans in the Profession. Learn more about the program by visiting http://www.apsanet.org/content_3284.cfm.

The 2013-14 Fellows are:

Angie Bautista-Chavez, Rice University

Andrew Brooks, University of Tulsa

Shakari Byerly, University of California, Los Angeles

Liwu Gan, Willamette University 